\title{
Asset or Liability? Ecological and Sociological Tradeoffs of Urban Spontaneous Vegetation on Vacant Land in Shrinking Cities
}

\author{
Christopher B. Riley ${ }^{1, *}$, Kayla I. Perry ${ }^{1}$ (D), Kerry Ard ${ }^{2}$ (1) and Mary M. Gardiner ${ }^{1}$ (D) \\ 1 Department of Entomology, The Ohio State University, Columbus, OH 43210, USA; \\ perry.1864@osu.edu (K.I.P.); gardiner.29@osu.edu (M.M.G.) \\ 2 School of Environment and Natural Resources, The Ohio State University, Columbus, OH 43210, USA; \\ ard.7@osu.edu \\ * Correspondence: riley.595@osu.edu; Tel.: +1-(614)-292-8209
}

Received: 16 May 2018; Accepted: 14 June 2018; Published: 22 June 2018

\begin{abstract}
The increase of minimally managed vacant land resulting from population loss and the subsequent removal of infrastructure is a reoccurring feature in shrinking cities around the globe. Due to the low frequency and intensity of management, these spaces create a unique environment for plant colonization, establishment, and succession. Herein we refer to these plants and the habitats they form as urban spontaneous vegetation (USV). As a form of urban green space, USV has the potential to provide a number of ecological and sociological benefits to shrinking cities, such as supporting urban wildlife, enhancing the provision of regulating ecosystem functions and services, connecting residents with nature, and improving human health and well-being. Conversely, USV can also support undesirable animals such as vectors of disease, and due to its wild and disorderly appearance, can evoke negative emotions in residents while signaling community neglect. This review aims to explore the potential ecological and sociological tradeoffs of USV within the context of shrinking cities. Through this evaluation, we aim to inform future planning and management to exploit the benefits offered by this resource while minimizing negative outcomes, thereby leading to the enhanced sustainability of shrinking cities worldwide.
\end{abstract}

Keywords: biodiversity; brownfield; conservation; informal green space; insect; novel ecosystem; wasteland; wildlife

\section{Introduction}

Shrinking cities are urban areas experiencing significant population decline as a result of economic restructuring, demographic change, suburbanization, and / or political transformation [1-4]. Worldwide, over 360 cities with a population exceeding 100,000 are shrinking, with $25 \%$ of these occurring in the United States alone [5]. For example, Detroit, MI, Cleveland, OH, St. Louis, MO, and Pittsburg, PA have each lost over $50 \%$ of their historical peak populations [6]. With such stark population losses and stagnant or depressed economies, ecosystems undergo major shifts in structure and function and remaining populations face a variety of social issues [7-9]. In this context, two processes are likely to occur: (1) vacant land increases as an overabundance of unused infrastructure is demolished [10]; and (2) municipalities become burdened with increasing maintenance costs of this land along with dwindling tax revenue [11]. The result is that vacant land often experiences minimal management relative to social norms and provides a setting for ecological processes such as plant colonization and succession to occur largely unimpeded (Figure 1) [12]. Plants that successfully colonize and establish on vacant land will herein be referred to as urban spontaneous vegetation (USV). 
USV can be defined at an individual plant or habitat scale. As individual entities, USV can refer to any plants that "colonize naturally without cultivation" [13] or "develop without intentional horticultural input" [14]. As a habitat, USV describes aggregations of spontaneous plant communities that undergo successional dynamics in the absence of human interference. We focus specifically on USV within the context of vacant land, and examine its ecological and sociological tradeoffs within shrinking cities.

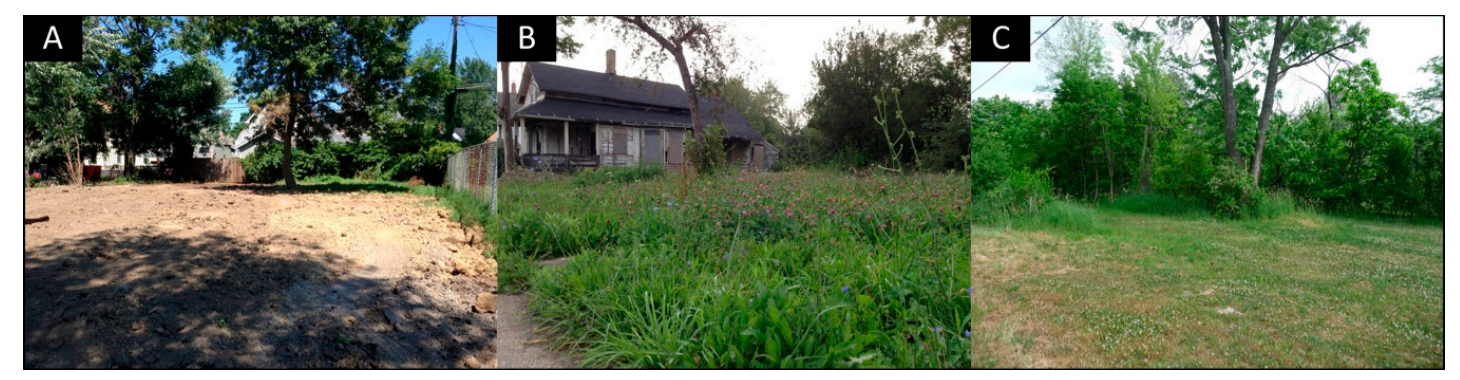

Figure 1. (A) Following the demolition of residential buildings, vacant lots in Cleveland, $\mathrm{OH}$, are seeded with a turfgrass seed mixture. (B) Common species readily colonize and diversify these sites, and regular mowing maintains the interior of each lot in an early successional state. (C) Fence lines, wooded areas, and/or lot perimeters often go unmanaged, which creates space for woody plants to colonize, establish, and persist.

In recent decades, research interest in describing, classifying, and elucidating the value of novel ecosystems has increased, including those dominated by USV [15-23]. Several conceptual frameworks have been proposed to describe these habitats, which have resulted in ambiguity within this interdisciplinary body of literature [20,21]. Novel ecosystems were defined by Hobbs et al. [24] as unique systems characterized by new species combinations that are the result of deliberate or inadvertent human action. Alternatively, the "four natures approach" as developed by Kowarik $[19,25,26]$ presents a typology for classifying urban nature based on its degree of transformation resulting from urbanization, with the continuum ranging from pristine remnants of natural ecosystems (Type 1 Nature) to the spontaneous plant communities occurring on urban-industrial sites (Type 4 Nature). Most recently, "informal green space" has been formally proposed to describe various types of novel urban green space including "urban wildscapes" [27] and "urban wilderness" [28] and has been defined as "any urban space with a history of strong anthropogenic disturbance that is covered at least partly with non-remnant, spontaneous vegetation" [21]. As described by Rupprecht and Byrne [21], informal urban green space is an explicitly socio-ecological entity that can include vacant land, rights-of-way such as railways and power lines, structural elements such as green roofs or vegetation on vertical structures, riparian corridors, and other disturbed microsites. In this review, we use the term vacant land to include post-industrial sites, derelict land, abandoned land, wasteland, land supporting abandoned infrastructure, and uncultivated or marginal agricultural land that resides within the urban matrix [15,29-31].

The USV occupying vacant land has the potential to provide ecological and social value to shrinking cities [11,32]. These plants are site-adapted [14] and tolerant of the many stressors characteristic of urban environments $[33,34]$. Plant communities on vacant land can become diverse over time [18,35-38] and even contain rare or threatened species [37-40]. These habitats have also been shown to support a variety of animal taxa $[17,20,41]$, including species of conservation concern and those not found on other types of urban green space [42-44]. USV can contribute to the provisioning of a variety of regulating ecosystem functions and services in shrinking cities $[13,16,45,46]$. It also has the potential to positively influence human health and well-being and enhance community social cohesion by providing opportunities for residents to experience nature, recreate, and interact with one another [16,47-54]. Neighborhoods with large holdings of vacant land often have the least access to formal urban green spaces [50]. Vacant land could mitigate environmental inequities 
by providing a cost-effective means of green space development (but see [55]). However, USV can also pose ecological challenges when aggressive native or non-native plant species dominate the community $[36,45,56-58]$ or it supports undesirable wildlife $[59,60]$. Furthermore, this type of novel urban nature can be perceived negatively by neighborhood residents [17,61-64], particularly in high-vacancy neighborhoods that are commonplace throughout shrinking cities [45].

This review examines how the USV occupying vacant land can be viewed as an asset, liability, or even both within an urban social-ecological framework [65]. Our goal was to synthesize ecological examinations of USV's conservation value and environmental risks with sociological investigations of aesthetic preferences and perceptions of urban nature within the context of shrinking city communities. We begin by examining the ecology of USV on vacant land, focusing on plant adaptations to urbanization, the prevalence of exotic species, and its potential to support biodiversity and contribute to ecosystem functions and services. Next, we focus on human aesthetic preferences for and perceptions of USV and how these can influence its use and potential to deliver cultural ecosystem services. Finally, we examine strategies to mitigate negative perceptions of USV held by community members and address knowledge gaps that are key to quantifying the ecological and sociological value of vacant land in shrinking cities.

\section{Ecological Considerations of USV}

A defining feature of USV is its ability to overcome the challenges associated with urban environments in the absence of human intervention [32]. Habitat loss and fragmentation, including changes in the abundance, quality, composition, and configuration of available habitat, are major landscape-scale filters of the plant species pool in urban ecosystems [66]. Plant species that persist following habitat loss and fragmentation must navigate a variety of environmental filters unique to urban ecosystems to successfully colonize and establish [33,66,67]. Across cities, plant communities contend with altered hydrological cycles, elevated levels of carbon dioxide and air pollution, higher temperatures, lower relative humidity, and longer growing seasons [34,67-70]. Several functional traits are indicative of a plant's success under these environmental conditions. For instance, plant traits such as seed mass, height, and woodiness are expected to increase with increasing urbanization [71]. Urban-adapted plants often exhibit a biennial or perennial life span or "competitor" life strategy and are likely to be wind-pollinated, mid-summer flowering, reproduce via seed or vegetatively, utilize wind or animal-mediated seed dispersal, and have high light and nutrient requirements [72]. Despite these general patterns, many of the plants occupying vacant land may lack some or all of these life history traits and strategies [73]. The abiotic conditions present within individual vacant lots can vary widely within and among cities, which can influence a given species' colonization success and persistence. For example, soil on vacant land can be alkaline from the erosion of lime-containing concrete, or acidic due to deposition of emissions [34,74]. Vacant land also varies in slope, aspect, soil compaction and contamination, and landscape context which can influence the composition of USV supported within the habitat $[34,67,71,74]$.

Despite the strong environmental filters imposed on USV, the plant communities on vacant land are often diverse, and in some instances, more so than comparable urban or rural habitats $[13,18,38,40,45,75-79]$. For example, more tree species were documented on vacant lots in inner-city Cleveland, $\mathrm{OH}$ than on residential properties [45]. Similarly, vacant land across four cities in Egypt supported more plant species than lawns, home gardens, public gardens, and desert habitat fragments [77]. Communities of USV occupying these habitats have been shown to enhance local and landscape plant diversity within cities, especially when allowed to undergo prolonged periods of succession with minimal human involvement $[18,35,37-39,57,80]$. For example, 262 vascular plant species were recorded over 20 years in a landfill in Berlin, Germany, with 229 species occurring by the sixth year of succession [38]. Of the 65 woody taxa recorded, 35 were tree species, representing more than $60 \%$ of the native and naturalized tree flora of the region [38]. In Paris, France, over 360 plant species were observed on wastelands, comprising $58 \%$ of the total plant richness in the 
broader metropolitan area [39]. Rare plants have also been documented on vacant land such as a regionally rare orchid, Orchis militaris L., and seven Red List species in Berlin, Germany [38,81].

However, many of the plants contributing to the high vegetation richness in cities are non-native [82]. Cities are points of introduction for non-native plant species, which comprise an average of $28-40 \%$ of urban flora worldwide [83-85]. Importantly, USV is not always dominated by non-native species $[36,37,40,86,87]$, however, these plants are a common occurrence within vacant land and can make up a substantial part of the species richness and abundance present $[45,88]$. For instance, non-native plants accounted for almost half $(48 \%)$ of woody plant total stem density on regenerated forest patches in Syracuse, NY [88]. In Cleveland, $\mathrm{OH}$, non-native trees were more abundant than native trees within vacant lots [45]. Many environmental costs have been associated with the adaptability and prolific success of these non-native plant species [89], and the economic and ecological costs of invasive species may be a liability for conservation initiatives in urban environments. Invasive plants can impact: (1) ecosystems by altering nutrient cycling, depleting available water, and changing fire regimes; (2) higher trophic levels by modifying resource availability and habitat heterogeneity; and (3) plant communities by displacing native competitors [90-92]. For example, Lantana camara (L.), considered to be among the world's ten worst invasive weed species, rapidly colonizes urban vacant land throughout India and its allelopathic effect can inhibit the recruitment of other species [93-95]. The population of the invasive common buckthorn (Rhamnus cathartica L.) increased by over $260 \%$ in Syracuse, NY in just 20 years, with $15 \%$ of the new individuals occupying vacant land [96]. Common buckthorn can alter ecosystem processes in the invaded range by forming dense thickets, expediting leaf litter decomposition, and altering soil nitrogen and carbon cycling [92]. Despite these costs, non-native USV has the potential to support higher trophic levels, increase community productivity, and deliver the majority of ecosystem services such as atmospheric carbon storage and sequestration and stormwater runoff reduction in certain settings (Figure 2) [32,45,91,97,98].

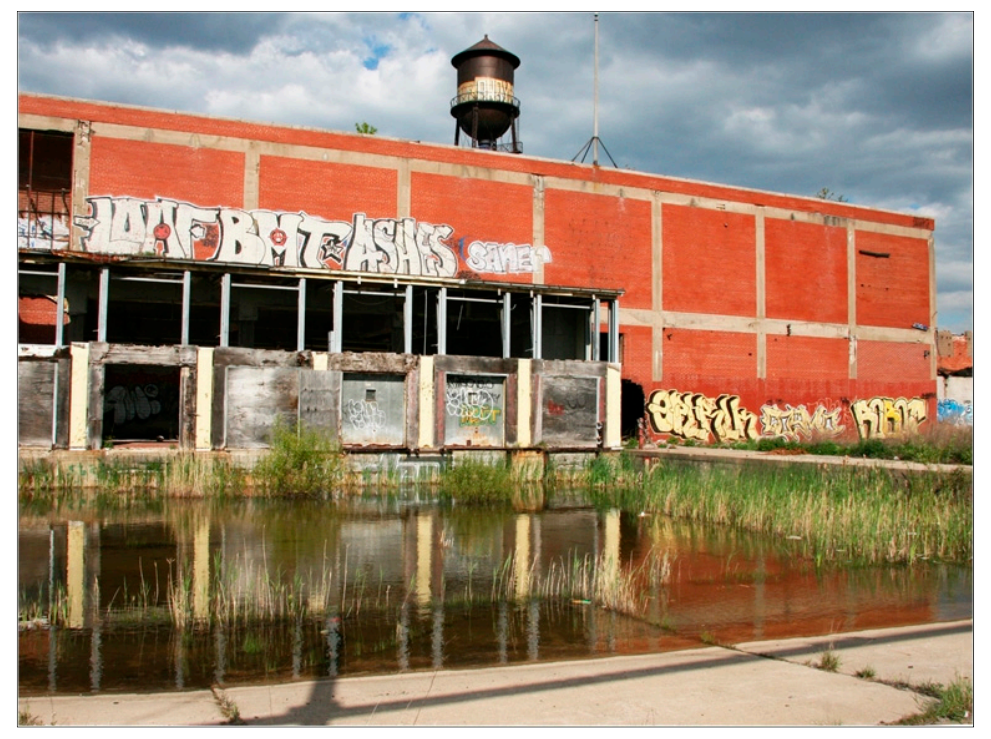

Figure 2. Photograph of a wetland illustrating the tradeoffs associated with urban spontaneous vegetation's tolerance of urban environments. In Detroit, MI, what is most likely the highly aggressive invading subspecies (P. australis australis) of the common reed, Phragmities australis (Cav.), has colonized an abandoned factory loading dock. From a conservation standpoint, the proliferation of an aggressive invasive species is undesirable, and this wetland may serve as a source habitat for its dispersal into the surrounding landscape. However, the reed has modified the space to enhance regulating ecological functions and services such as atmospheric carbon sequestration and storage and stormwater runoff reduction. The question of whether such habitats should persist given these tradeoffs is important for ecologists and urban planners. Photograph by Dr. Peter Del Tredici. 
Urbanization is a major driver of wildlife population declines [33,85]. Consequently, major efforts have been undertaken to document the wildlife able to persist in cities and assess any conservation potential of urban habitats under various management regimes $[12,18,20,67,99,100]$. Several researchers have described the rich diversity of animal species observed in these habitats, including populations of arthropods, birds, and mammals [17,18,20,41]. Arthropods in particular have been studied extensively in urban ecosystems $[12,13,17,42-44,101-111]$ and have been identified as reasonable conservation targets for vacant land management due to their small patch size requirements, high capacity for dispersal, and contribution to ecosystem functions and services [17,112-114]. Vacant land has been found to support rare arthropods, including 46 nationally rare and scarce beetle species in England [42] and 63 ground beetle species in Britain, with two considered nationally scarce [43]. As with plant species, the arthropod fauna occupying vacant land is often richer and more abundant than other urban habitat types. Vacant lots supported unique beetle and ant species [44,110], higher activity densities of spiders and harvestmen $[108,109,111]$, and higher abundance and richness of pollinators $[13,107]$ than other types of urban green space. These findings suggest that habitats with USV may contribute to arthropod conservation in cities.

Common and endangered avian species have been documented to utilize vacant land for foraging and nesting [115-119]. Avian communities are shaped by conditions such as patch size, vegetation height, food availability, surrounding landscape context, and the frequency of human disturbance occurring within a habitat $[41,115,116,118-122]$. For example, success of endangered wheatear (Oenanthe oeanthe L.) nests was largely influenced by habitat size, with vacant land larger than five hectares having a higher probability of wheatear occurrence [116]. Breeding pairs of grey partridge (Perdix perdix L.) were observed in 73-81\% of unmanaged vacant patches in the suburbs of Prague, Czech Republic, with larger patches correlated with more breeding pairs [115]. Vegetation structure across 55 urban vacant sites in Berlin, Germany had a strong influence on the occurrence of bird species of European conservation concern [122]. In Europe, densities of house sparrow (Passer domesticus L.) on vacant land and poorly maintained allotments were higher than or comparable to those observed on other types of urban land use [118,119]. Vacant lots in Baltimore, MD were actively used by 60 different species of birds for foraging and nesting, with those lots with greater shrub cover associated with more nesting attempts [120]. Mammals, reptiles, and amphibians, on the other hand, have received comparatively less attention in the context of USV habitats [18,20]. In Paris, France, the Petite Ceinture is an abandoned railway encircling the city that serves as habitat for common small to midsized mammals such as hedgehogs and foxes [123]. Larger mammals have also been documented to utilize vacant land within their range. While not their primary urban habitat type, coyotes in Tucson, AZ spent $8 \%$ of their nocturnal activity on vacant land despite this land use type occupying only $3 \%$ of the study area [124]. Reptile and amphibian species may inhabit vacant land in cities as well, dependent on the environmental conditions present within the patch and its surrounding landscape context [125-127].

Many of the same habitat features that draw desirable wildlife to vacant land can attract opportunistic species such as rats, raccoons, feral cats, ticks, or mosquitoes as well as invasive pests such as brown marmorated stink bug (Halyomorpa halys Stål) and spotted lanternfly (Lycorma delicatula White) [60]. The proximity to human populations of and the potential for human-wildlife conflicts posed by these species illustrates a significant tradeoff associated with these habitats [59,60,128-130]. Four distinct types of human-wildlife conflict can arise from undesirable animals: (1) aggression, injury, and death; (2) nuisance and property damage; (3) disease; and (4) economic cost [131]. Tree of heaven (Ailanthus altissima (Mill.) Swingle) is a preferred host of the agricultural and ornamental pests brown marmorated stink bug and spotted lanternfly in the United States, and its prevalence on vacant land may facilitate their range expansion while further exacerbating undesirable human-animal interactions $[45,132,133]$. As vectors of diseases such as West Nile virus and chikungunya virus, native and introduced mosquitoes are undesirable pests that may benefit from the abundance of USV in shrinking cities. Abundances of vacant land and USV on city blocks with high abandonment were positively associated with mosquito populations [128,129]. However, within high-vacancy 
neighborhoods, mosquito abundance was unaffected by periodic mowing of USV, suggesting that reduced management approaches targeted at species of conservation concern such as wild bee populations may not result in unintended public health concerns [106]. Citizen awareness of perceived and actual risks posed by these unwanted species as well as investigations into which factors influence the use of vacant land by undesirable wildlife are key to advancing vacant land as a conservation habitat in shrinking cities.

The regulating ecosystem functions and services provided by urban green space have received considerable attention over the past two decades [134-136]. Regulating functions are essential ecological processes and life support systems such as bio-geochemical cycles and biospheric processes [135], while regulating services are the human benefits obtained from the regulation of these ecosystem processes [137]. In shrinking cities, vacant land can directly and indirectly contribute to several regulating urban ecosystem services, including: (1) urban temperature regulation; (2) noise reduction; (3) air purification; (4) moderation of climate extremes; (5) runoff mitigation; (6) waste treatment; (7) pollination, pest regulation, and seed dispersal; and (8) global climate regulation [138]. USV is key to the provision of these functions and services, which on vacant land can exceed that provided by other urban land use types [16]. For example, vacant lots in inner-city Cleveland, $\mathrm{OH}$ contained more trees and provided more regulating ecosystem services per hectare than residential lots [45]. Similarly, woody plants found on vacant land in Roanoke, VA stored more carbon per hectare than the plants on commercial or industrial land [139]. Vacant land has also been found to support a greater richness and abundance of insect pollinators than other urban habitat types, which could provide greater pollination services within these spaces and surrounding habitats [13]. Maintaining USV in various successional stages on vacant land is therefore a prudent strategy for the continued provisioning of these and other ecosystem services within shrinking cities.

\section{Sociological Considerations of USV}

Vacant land dominated by USV has the potential to provide a number of benefits to residents of shrinking cities. There is growing alienation between humans and the natural world [140,141]. Vacant land may be uniquely capable of increasing green space access, which can be limited within inner-city neighborhoods and disadvantaged communities [50]. There is evidence that by facilitating active and passive interactions with nature, urban green spaces can positively impact human's psychological, cognitive, and physiological well-being [47,50-52], but see [142]. For example, spontaneous plants growing in novel locations, such as on vertical wall surfaces, represent priceless urban ecological heritage to residents of many cities that is free for all to appreciate $[76,87,143]$. Furthermore, there is no financial cost associated with USV colonization and establishment, which is important to shrinking cities experiencing declining tax revenue [11,144]. Inputs such as water, fertilizers, and pesticides are rarely, if ever, used to manage vacant land, making the habitat an economically feasible way to combat issues of environmental inequity and provision ecosystem services such as shading and atmospheric pollutant removal across shrinking cities (Figure 3) [45]. However, there are also potential costs associated with USV management such as trimming or removal of woody plants to prevent damage to fences or power lines, removal of fallen leaves from gutters, and expenses incurred when limbs fall or when roots grow into concrete, asphalt, or the basements of buildings (Figure 3) [59,76]. From a sociological standpoint, the value of vacant land is therefore largely contingent on how USV is perceived, utilized, and managed by community members and municipalities $[63,64,145]$. 

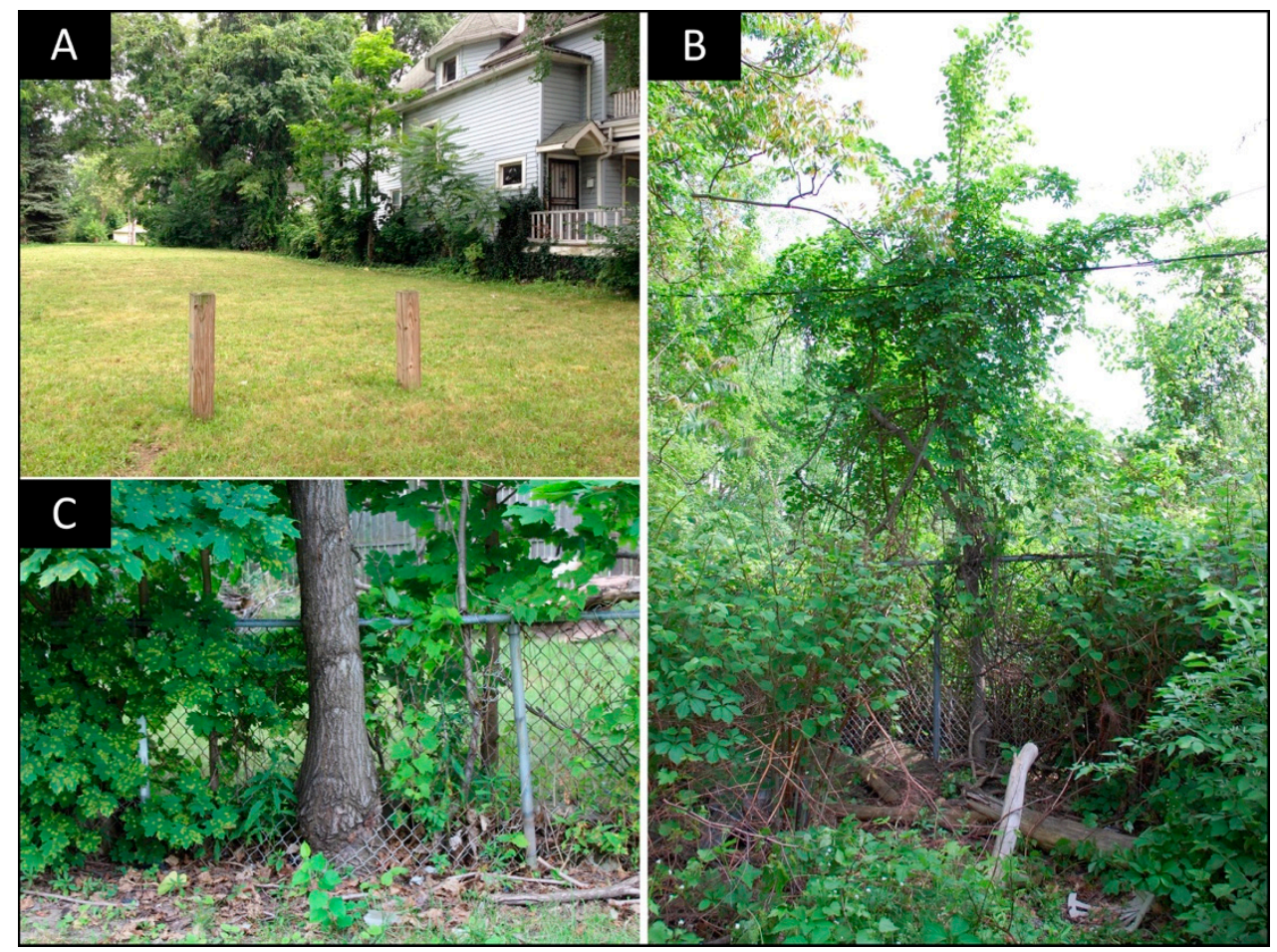

Figure 3. Urban spontaneous vegetation can be an asset and liability from a monetary standpoint. (A) When left to mature undisturbed, larger trees that began as spontaneously establishing seedlings can provide shade and privacy. Alternatively, woody plants can (B) grow near or on transmission wires or infrastructure or (C) establish in fences or around fence lines and damage them as they grow, with both outcomes leading to management costs and potentially repairs.

When vacant land supports USV, it has the potential to address race- and income-based inequities in access to urban green space, which have been well documented (Figure 4) [50,146-149], but see [55]. Proximity to parks has been linked with increased physical activity whereas a lack of green space access is linked to negative health outcomes [50]. In neighborhoods with limited park access, vacant land may serve as a viable alternative space for physical activity and recreation $[11,16,53,63,64,145]$. For instance, surveys in Japan and Australia found that many residents utilize informal green spaces such as vacant land for recreation, with proximity cited as an important feature [11,145]. There is also evidence that accessible green spaces promote social cohesion and strengthen community relationships, which can influence resident health outcomes [47,48,150-152]. For example, residents of public housing buildings in Chicago, IL were more likely to use common spaces and socialize with neighbors when vegetation was present [151]. The development of social cohesion can contribute to the formation of social capital [47], which is often depleted within high vacancy neighborhoods [153]. Vacant land can serve as a unique space for experiential learning, which is important for combatting the growing alienation between humans and the natural world $[140,141,154]$. Childhood is a critical time to connect individuals with nature and when given access to appropriate spaces, children will readily do so (Figure 5) [140,155]. Because more highly manicured green spaces are often inadequate for children's exploration and self-teaching, vacant lots have been suggested as "second hand land" wherein ecological processes can be observed and an appreciation for nature garnered (Figure 5) [54,140]. 


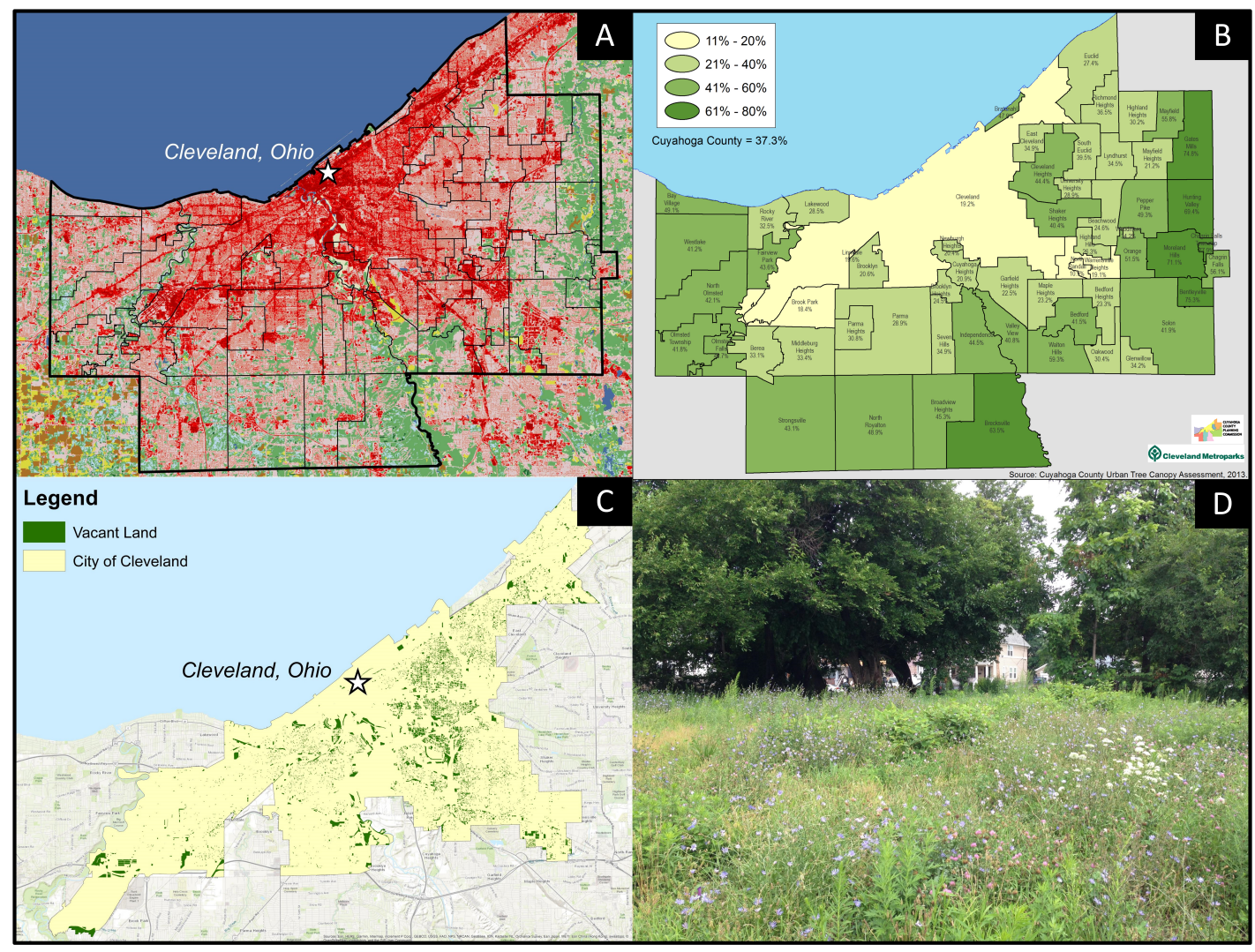

Figure 4. (A) Cities are dominated by impervious surface (red) relative to their outlying suburbs, as illustrated here for Cleveland, OH. (B) The city of Cleveland has one of the lowest percentages of tree canopy cover (11-20\%) of all municipalities in Cuyahoga County [156]. (C) At the same time, Cleveland has over 27,000 vacant lots spanning more than 14 square kilometers [17,45]. (D) Early successional vacant lots resembling grassland have the potential to provide many of the same functions as neighborhood parks, such as places for socializing, recreation, and relaxation. If afforestation is allowed to occur, vacant land can also address inequities in urban tree canopy cover across the municipality. Land cover data for Map A comes from National Land Cover Database 2011 [157]; Map B included with permission from [156]; and map C adapted with permission from [158].

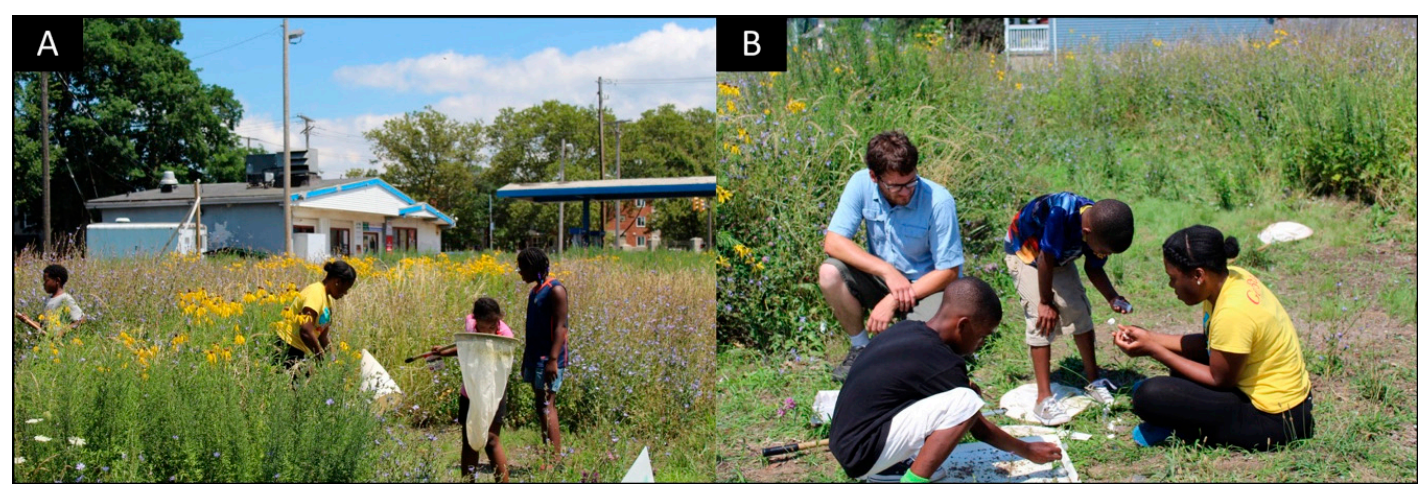

Figure 5. With USV often being more ecologically diverse than traditional turfgrass lawns, countless opportunities exist to use these spaces as nature education tools. This "pocket prairie" in Cleveland, $\mathrm{OH}$ was seeded with native Ohio wildflowers and contains a mixture of planted species and USV. (A) At a community event, graduate and undergraduate students from The Ohio State University taught children how to use sweep nets to collect arthropods from the plot. (B) To take a closer look, participants placed their captured specimens in vials for identification. 
Importantly, deriving many cultural ecosystem services requires that USV's aesthetics are positively perceived by neighbors, which may often not be the case $[62,153,159]$. USV's unifying characteristic is its wild and disorderly nature [12], and this aspect is frequently perceived negatively by community members $[8,63,64,160]$. For example, residents' perceptions of USV were positive when the habitat was viewed as natural or capable of supporting recreation and negative when it was regarded as wild or abandoned, terms often prescribed to vacant land [63,64]. Even when USV is managed periodically (e.g., mown monthly over the growing season), it can continue to be perceived as having a wild appearance compared with other common green spaces such as residential lawns or parks. Negative perceptions of USV may be particularly common within the urban core of shrinking cities, where high concentrations of unutilized vacant land exist $[158,161]$. An abundance of USV proliferating across blocks of vacant land is unlikely to signify community character and opportunity, but rather neglect and a lack of 'cues to care' to many residents [153,162,163]. Vegetative landscape components such as mown turf, trimmed trees and hedges, and plants in neat rows are common cues to care in urban settings [153], and USV does not align with these examples. When cues to care are absent, and disorder prevails, residents may experience physical and/or social isolation from their neighbors, increased feelings of hopelessness, and diminished social capital $[153,164,165]$.

Beyond aesthetic preferences, USV is unlikely to be utilized if it is perceived unsafe or encourages antisocial behaviors $[166,167]$. Historically, there has been a persistent view that vegetation facilitates crime (reviewed in $[168,169])$. More recently, a paradigm shift has occurred with emerging evidence that greening may in fact be beneficial for reducing crime [168-172]. The two mechanisms that have been proposed as mediators of this relationship are increased neighborhood surveillance and alleviation of physiological precursors to violent behavior [169]. At the scale of entire cities, greater vegetation abundance or canopy cover has been associated with lower rates of crime [169,172]. Installing cues to care within vacant lots (e.g., planting grass and trees, removing trash, installing fences [153]) is also associated with lower rates of crime in surrounding neighborhoods $[170,171]$. However, these efforts require enhanced levels of management and human intervention $[170,171,173]$. For example, in the greening program employed by Branas et al. [170], the protocol called for, "... removing trash and debris, grading the land, planting grass and trees to create a park-like setting, and installing low wooden post-and-rail fences around each lot's perimeter to show that the lot was cared for and deter illegal dumping". These activities signal community engagement and social cohesion, and could possibly shift community perceptions away from USV being associated with greater criminal activity. Additional eyes on the street may also serve as a deterrent to criminal activity [169]. Residents of shrinking cities are certainly capable of developing community programs and initiatives to implement these greening strategies. However, given questions of depleted financial and social capital in these neighborhoods, there may be barriers to the implementation of these types of initiatives.

\section{Conclusions and Future Research Directions}

In this paper, the ecological and sociological tradeoffs surrounding USV on vacant land within the context of shrinking cities were reviewed. Spontaneous plants and plant communities can be regarded as ecological assets when considering their tolerance of urban environments, potential to be highly diverse and support unique wildlife, and contribution to the provisioning of regulating ecosystem functions and services. Conversely, USV can also be regarded as an ecological liability when dominated by undesirable plant species or supporting undesirable animals such as vectors of disease. From a sociological standpoint, USV has the potential to improve human health and well-being and connect residents with nature, all with no monetary cost of plant establishment or persistence. Its disorderly appearance, however, can evoke fear of crime in residents and signal community neglect, and its management can pose financial burdens on municipalities or residents. Although USV provides non-trivial ecological value within the urban matrix, it is likely to continue to be viewed as low-quality green space or blight in high-vacancy neighborhoods within shrinking cities. While it might seem reasonable to advocate for USV's conservation in an unmanaged state from an 
ecological standpoint, doing so without considering the perspective or interests of local stakeholders would be naive, and would almost certainly lead to conflict between groups with divergent interests as well as wasted resources. If the human community does not factor the ecological value of USV into their value judgment, or worse yet, experiences fear or diminished social cohesion from its presence, there will always be pushback to the continued existence of these spaces in one of their most ecologically valuable forms (i.e., various stages of wild successional habitat).

Pickett and colleagues [65] make the argument that urban ecology is represented by three unique paradigms: ecology in, of, and for the city. Ecology in the city focuses on investigations into ecological habitats and processes that happen to occur within an urban matrix. Ecology of the city represents an expansion of scope wherein consideration is also given to the social processes occurring within urban areas and how they shape and interact with the ecological ones. Ecology for the city is a paradigm that adopts a philosophy grounded in stewardship of the urban social-ecological system. In other words, ecology for the city "is the application of a social-ecological understanding to shaping urban form and function along sustainable trajectories" [10]. Given the abundance of minimally managed parcels of land in shrinking cities worldwide, the variety of challenges they pose, and their precarious position as blight-with-the-potential-to-be-more, there is a great need for a holistic understanding of these landscape elements that can contribute to actionable outcomes that benefit all stakeholders [174]. In concordance with this notion, Nassauer and Raskin [153] state, "an understanding of the relationships among associated social, institutional, and ecological processes associated with vacant urban land is vital to framing actionable research".

Towards this understanding, future research on USV in the social-ecological system of shrinking cities should continue to examine its ecological role and conservation potential while also investigating ways in which the human community's perception of habitats with USV could be improved. From an ecological standpoint, there are gaps in our understanding of the value of USV for taxa other than arthropods and birds, as well as a paucity of research that goes beyond abundance and diversity assessments to examine how these habitats might be functioning for the persistence of populations and/or communities. Shwartz et al. [175] highlight that documenting the presence of target species is not an indication of effective conservation considering the possibility of urban habitats acting as ecological traps. Research examining the role and value of these habitats for metapopulation persistence (e.g., source-sink dynamics, role in facilitating dispersal/migration), survivorship (e.g., food availability, availability of enemy free space), reproduction (e.g., nesting suitability, mate finding), overwintering, and species interactions (e.g., predation, pollination, parasitism, disease transmission, missed mutualisms, direct and indirect completion) is needed. Additionally, with USV often occurring on land with a history of contamination, there is a need to understand how these plants might be contributing to the transfer of pollutants such as heavy metals to higher trophic levels, and how bioaccumulation might impact the ecological processes described above. From a sociological standpoint, research on the effectiveness of various management plans for USV aimed at improving community perceptions and likelihood of engaging in healthy activities within the sites are needed. For example, efforts to mitigate conflict between optimal ecological and sociological outcomes could be demarcated via cues to care such as adding fencing, planting trees, or developing walkways (Figure 6A) as well as low-cost alternatives such as educational signage or linear mown edges around the perimeter of the space (Figure 6B). Alternatively, cities could offer incentive programs to community members wherein nearby adjacent parcels of land are managed through low-intensity strategies (i.e., perimeter edge mowing) that create urban conservation spaces. These management efforts would enable succession to occur, and in some places afforestation, within a managed framework ("ordered succession") [63]. However, their utility in addressing negative perceptions of USV could vary among cities or neighborhoods and should be studied locally prior to investment and implementation. If these programs are successful at cultivating a sense of community among residents, improving neighborhood aesthetics and human health, and ameliorating the economic blight associated with vacancy, issues related to environmental gentrification could emerge [50]. Questions therefore exist as to whether 
increases in USV as a result of increases in available habitat are coinciding with gentrification, and if not, whether greening initiatives might then contribute to gentrification issues.

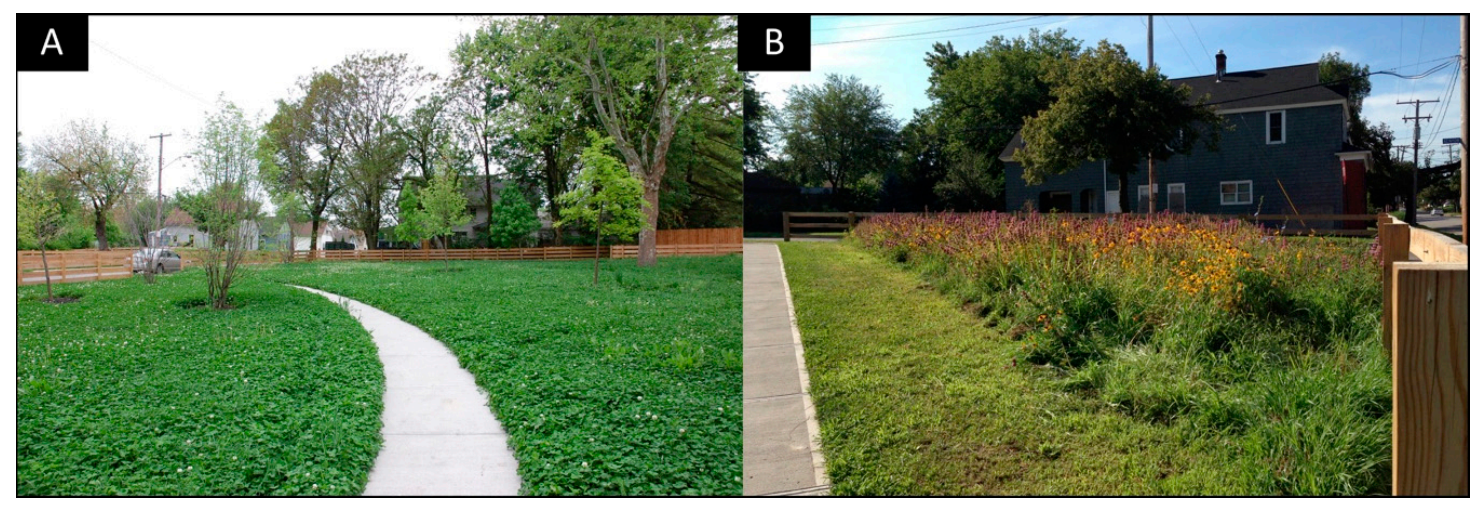

Figure 6. Management efforts that frame the disorderly appearance of USV may alleviate some of the negative perceptions associated with it while maintaining its ecological value. (A) Several continuous vacant lots have been fenced off, trees planted, and a walk way constructed through a variety of herbaceous species that will be permitted to mature and take on a wild character. (B) An even more cost-effective alternative could involve creating linear mown edges around patches of otherwise unmanaged vegetation.

Author Contributions: C.B.R. developed the main ideas presented in the manuscript with conceptual advice from M.M.G. C.B.R. prepared the original draft of the manuscript. All authors reviewed, edited, and revised subsequent iterations of the manuscript. All authors approved the final manuscript.

Funding: This work was supported by funding from the National Science Foundation Graduate Research Fellowship Program (DGE-1343012) to C.B.R., USDA NIFA Food, Agriculture, Natural Resources and Human Sciences Education and Literacy Initiative Postdoctoral Fellowship (2018-67012-28011) to K.I.P., and a Division of Environmental Biology CAREER Grant (CAREER-1253197) and USDA Agricultural Research Program Initiative Foundational Programs Grant (2017-67013-26595) to M.M.G.

Acknowledgments: The authors would like to thank Dustin Herrmann for providing the opportunity to contribute to this special issue on shrinking cities. They would also like to thank Sarah Scott for her time and effort drawing and painting the tree featured in the graphical abstract. Three anonymous reviewers provided helpful comments that improved this manuscript.

Conflicts of Interest: The authors declare no conflict of interest.

\section{References}

1. Bernt, M.; Cocks, M.; Couch, C.; Grossmann, K.; Haase, A.; Dieter, R. Policy Response, Governance and Future Directions. 2012, pp. 1-17. Available online: https:/ /www.ufz.de/export/data/400/39031_ResearchBrief2_ .pdf (accessed on 4 April 2018).

2. Buhnik, S. From shrinking cities to Toshi no Shukushō: Identifying patterns of urban shrinkage in the Osaka Metropolitan Area. Berkeley Plan. J. 2010, 23, 132-155. [CrossRef]

3. Wiechmann, T. Errors expected-Aligning urban strategy with demographic uncertainty in shrinking cities. Int. Plan. Stud. 2008, 13, 431-446. [CrossRef]

4. Schatz, L.K. What Helps or Hinders the Adoption of "Good Planning" Principles in Shrinking Cities? A Comparison of Recent Planning Exercises in Sudbury, Ontario and Youngstown, Ohio. Ph.D. Thesis, University of Waterloo, Waterloo, ON, Canada, 2010.

5. Haase, D. Chapter 12: Shrinking cities, biodiversity and ecosystem services. In Urbanization, Biodiversity and Ecosystem Services: Challenges and Opportunities: A Global Assessment; Springer: Dordrecht, The Netherlands, 2013.

6. Herrmann, D.L.; Shuster, W.D.; Mayer, A.L.; Garmestani, A.S. Sustainability for shrinking cities. Sustainability 2016, 8, 911. [CrossRef]

7. Haase, D.; Haase, A.; Rink, D. Conceptualizing the nexus between urban shrinkage and ecosystem services. Landsc. Urban Plan. 2014, 132, 159-169. [CrossRef] 
8. Hollander, J.B.; Pallagst, K.; Schwarz, T.; Popper, F.J.; Hollander, J.B. Planning shrinking cities. Prog. Plan. 2009, 72, 223-232.

9. Martinez-Fernandez, C.; Audirac, I.; Fol, S.; Cunningham-Sabot, E. Shrinking cities: Urban challenges of globalization. Int. J. Urban Reg. Res. 2012, 36, 213-225. [CrossRef] [PubMed]

10. Herrmann, D.L.; Schwarz, K.; Shuster, W.D.; Berland, A.; Chaffin, B.C.; Garmestani, A.S.; Hopton, M.E. Ecology for the shrinking city. Bioscience 2016, 66, 965-973. [CrossRef]

11. Rupprecht, C. Informal urban green space: Residents' perception, use, and management preferences across four major Japanese shrinking cities. Land 2017, 6, 59. [CrossRef]

12. Kattwinkel, M.; Biedermann, R.; Kleyer, M. Temporary conservation for urban biodiversity. Biol. Conserv. 2011, 144, 2335-2343. [CrossRef]

13. Robinson, S.L.; Lundholm, J.T. Ecosystem services provided by urban spontaneous vegetation. Urban Ecosyst. 2012, 15, 545-557. [CrossRef]

14. Kühn, N. Intentions for the unintentional: Spontaneous vegetation as the basis for innovative planting design in urban areas. J. Landsc. Archit. 2006, 1, 46-53. [CrossRef]

15. Kim, G.; Miller, P.A.; Nowak, D.J. Urban vacant land typology: A tool for managing urban vacant land. Sustain. Cities Soc. 2018, 36, 144-156. [CrossRef]

16. Kim, G. The public value of urban vacant land: Social responses and ecological value. Sustainability 2016, 8, 486. [CrossRef]

17. Gardiner, M.M.; Burkman, C.E.; Prajzner, S.P. The value of urban vacant land to support arthropod biodiversity and ecosystem services. Environ. Entomol. 2013, 42, 1123-1136. [CrossRef] [PubMed]

18. Bonthoux, S.; Brun, M.; Di Pietro, F.; Greulich, S.; Bouche-Pillon, S. How can wastelands promote biodiversity in cities? A review. Landsc. Urban Plan. 2014, 132, 79-88. [CrossRef]

19. Kowarik, I. Novel urban ecosystems, biodiversity, and conservation. Environ. Pollut. 2011, 159, $1974-1983$. [CrossRef] [PubMed]

20. Rupprecht, C.D.D.; Byrne, J.A.; Garden, J.G.; Hero, J.M. Informal urban green space: A trilingual systematic review of its role for biodiversity and trends in the literature. Urban For. Urban Green. 2015, 14, 883-908. [CrossRef]

21. Rupprecht, C.D.D.; Byrne, J.A. Informal urban greenspace: A typology and trilingual systematic review of its role for urban residents and trends in the literature. Urban For. Urban Green. 2014, 13, 597-611. [CrossRef]

22. Threlfall, C.G.; Kendal, D. The distinct ecological and social roles that wild spaces play in urban ecosystems. Urban For. Urban Green. 2018, 29, 348-356. [CrossRef]

23. Hobbs, R.J.; Higgs, E.; Hall, C.M.; Bridgewater, P.; Chapin, F.S.; Ellis, E.C.; Ewel, J.J.; Hallett, L.M.; Harris, J.; Hulvey, K.B.; et al. Managing the whole landscape: Historical, hybrid, and novel ecosystems. Front. Ecol. Environ. 2014, 12, 557-564. [CrossRef]

24. Hobbs, R.J.; Arico, S.; Aronson, J.; Baron, J.S.; Bridgewater, P.; Cramer, V.A.; Epstein, P.R.; Ewel, J.J.; Klink, C.A.; Lugo, A.E.; et al. Novel ecosystems: Theoretical and management aspects of the new ecological world order. Glob. Ecol. Biogeogr. 2006, 15, 1-7. [CrossRef]

25. Kowarik, I. Wild urban woodlands: Towards a conceptual framework. In Wild Urban Woodlands; Springer: Berlin/Heidelberg, Germany, 2005; Chapter 1.

26. Kowarik, I. Urban wilderness: Supply, demand, and access. Urban For. Urban Green. 2018, $29,336-347$. [CrossRef]

27. Jorgensen, A.; Keenen, R. (Eds.) Urban Wildscapes; Routledge: Abingdon, UK, 2012.

28. Konijnendijk, C.C. Between fascination and fear-The impacts of urban wilderness on human health and wellbeing. Socialmed. Tidskr. 2012, 89, 289-295.

29. Bowman, A.O. Terra incognita: Vacant Land and Urban Strategies; Brookings Instituion, Center on Urban and Metropolitan Policy: Washington, DC, USA, 2004.

30. Pagano, M.A.; Bowman, A.O. Vacant Land in Cities: An Urban Resource; Brookings Institution: Washington, DC, USA, 2000.

31. Grădinaru, S.R.; Iojă, C.I.; Onose, D.A.; Gavrilidis, A.A.; Pătru-Stupariu, I.; Kienast, F.; Hersperger, A.M. Land abandonment as a precursor of built-up development at the sprawling periphery of former socialist cities. Ecol. Indic. 2015, 57, 305-313. [CrossRef]

32. Millard, A. The potential role of natural colonisation as a design tool for urban forestry a pilot study. Landsc. Urban Plan. 2000, 52, 173-179. [CrossRef] 
33. Grimm, N.B.; Faeth, S.H.; Golubiewski, N.E.; Redman, C.L.; Wu, J.; Bai, X.; Briggs, J.M. Global change and the ecology of cities. Science 2008, 319, 756-760. [CrossRef] [PubMed]

34. Sukopp, H. Human-caused impact on preserved vegetation. Landsc. Urban Plan. 2004, 68, 347-355. [CrossRef]

35. Hwang, Y.H.; Yue, Z.E.J.; Tan, Y.C. Observation of floristic succession and biodiversity on rewilded lawns in a tropical city. Landsc. Res. 2017, 42, 106-119. [CrossRef]

36. Albrecht, H.; Eder, E.; Langbehn, T.; Tschiersch, C. The soil seed bank and its relationship to the established vegetation in urban wastelands. Landsc. Urban Plan. 2011, 100, 87-97. [CrossRef]

37. Schröder, R.; Glandorf, S.; Kiehl, K. Temporal revegetation of a demolition site-A contribution to urban restoration? J. Urban Ecol. 2018, 4, 1-10. [CrossRef]

38. Rebele, F.; Lehmann, C. Twenty years of woodland establishment through natural succession on a sandy landfill site in Berlin, Germany. Urban For. Urban Green. 2016, 18, 182-189. [CrossRef]

39. Muratet, A.; Machon, N.; Jiguet, F.; Moret, J.; Porcher, E. The role of urban structures in the distribution of wasteland flora in the Greater Paris area, France. Ecosystems 2007, 10, 661-671. [CrossRef]

40. Prach, K.; Pyšek, P. Using spontaneous succession for restoration of human-disturbed habitats: Experience from Central Europe. Ecol. Eng. 2001, 17, 55-62. [CrossRef]

41. Meffert, P.J. Birds on urban wastelands. In Ecology and Conservation of Birds in Urban Environments; Springer: Berlin/Heidelberg, Germany, 2017; Chapter 19; pp. 399-411. ISBN 9783319433141.

42. Eyre, M.D.; Luff, M.L.; Woodward, J.C. Beetles (Coleoptera) on brownfield sites in England: An important conservation resource? J. Insect Conserv. 2003, 7, 223-231. [CrossRef]

43. Small, E.C.; Sadler, J.P.; Telfer, M.G. Carabid beetle assemblages on urban derelict sites in Birmingham, UK. J. Insect Conserv. 2003, 6, 233-246. [CrossRef]

44. Delgado de la Flor, Y.A.; Burkman, C.E.; Eldredge, T.K.; Gardiner, M.M. Patch and landscape-scale variables influence the taxonomic and functional composition of beetles in urban greenspaces. Ecosphere 2017, 8, 1-17. [CrossRef]

45. Riley, C.B.; Herms, D.A.; Gardiner, M.M. Exotic trees contribute to urban forest diversity and ecosystem services in inner-city Cleveland, OH. Urban For. Urban Green. 2017, 1-10. [CrossRef]

46. Tredici, P. Del Spontaneous Urban Vegetation: Reflections of Change in a Globalized World. Nat. Cult. 2010, 5, 299-315. [CrossRef]

47. Jennings, V.; Larson, L.; Yun, J. Advancing sustainability through urban green space: Cultural ecosystem services, equity, and social determinants of health. Int. J. Environ. Res. Public Health 2016, 13, 196. [CrossRef] [PubMed]

48. Hartig, T.; Mitchell, R.; de Vries, S.; Frumkin, H. Nature and Health. Annu. Rev. Public Health 2014, 35, 207-228. [CrossRef] [PubMed]

49. De Vries, S.; Verheij, R.A.; Groenewegen, P.P.; Spreeuwenberg, P. Natural environments-Healthy environments? An exploratory analysis of the relationship between greenspace and health. Environ. Plan. A 2003, 35, 1717-1731. [CrossRef]

50. Wolch, J.R.; Byrne, J.; Newell, J.P. Urban green space, public health, and environmental justice: The challenge of making cities "just green enough". Landsc. Urban Plan. 2014, 125, 234-244. [CrossRef]

51. Brown, C.; Grant, M. Biodiversity and human health: What role for nature in healthy urban planning? Built Environ. 2005, 31, 326-338. [CrossRef]

52. Sandifer, P.A.; Sutton-Grier, A.E.; Ward, B.P. Exploring connections among nature, biodiversity, ecosystem services, and human health and well-being: Opportunities to enhance health and biodiversity conservation. Ecosyst. Serv. 2015, 12, 1-15. [CrossRef]

53. Kamvasinou, K. The public value of vacant urban land. Munic. Eng. 2011, 164, 157-166. [CrossRef]

54. Pyle, R.M. Eden in a vacant lot: Special places, species, and kids in the neighborhood of life. In Children and Nature: Psychological, Sociocultural, and Evolutionary Investigations; MIT Press: Cambridge, MA, USA, 2002; Chapter 12, pp. 305-327.

55. Schwarz, K.; Berland, A.; Herrmann, D.L. Green, but not just? Rethinking environmental justice indicators in shrinking cities. Sustain. Cities Soc. 2018, in press.

56. Dunnett, N.; Nagase, A.; Hallam, A. The dynamics of planted and colonising species on a green roof over six growing seasons 2001-2006: Influence of substrate depth. Urban Ecosyst. 2008, 11, 373-384. [CrossRef]

57. Hwang, Y.H.; Yue, Z.E.J. Observation of biodiversity on minimally managed green roofs in a tropical city. J. Living Archit. 2015, 2, 9-26. [CrossRef] 
58. Dickie, I.A.; Bennett, B.M.; Burrows, L.E.; Nuñez, M.A.; Peltzer, D.A.; Porté, A.; Richardson, D.M.; Rejmánek, M.; Rundel, P.W.; van Wilgen, B.W. Conflicting values: Ecosystem services and invasive tree management. Biol. Invasions 2014, 16, 705-719. [CrossRef]

59. Lyytimäki, J.; Sipilä, M. Hopping on one leg-The challenge of ecosystem disservices for urban green management. Urban For. Urban Green. 2009, 8, 309-315. [CrossRef]

60. Goldstein, J.; Jensen, M.; Reiskin, E. Urban Vacant Land Redevelopment: Challenges and Progress; Lincoln Institute of Land Policy: Cambridge, MA, USA, 2001; Volume 37.

61. Draus, P.J.; Roddy, J.; McDuffie, A. 'We don't have no neighbourhood': Advanced marginality and urban agriculture in Detroit. Urban Stud. 2014, 51, 2523-2538. [CrossRef]

62. Lafortezza, R.; Corry, R.C.; Sanesi, G.; Brown, R.D. Visual preference and ecological assessments for designed alternative brownfield rehabilitations. J. Environ. Manag. 2008, 89, 257-269. [CrossRef] [PubMed]

63. Mathey, J.; Arndt, T.; Banse, J.; Rink, D. Public perception of spontaneous vegetation on brownfields in urban areas-Results from surveys in Dresden and Leipzig (Germany). Urban For. Urban Green. 2018, 29, 384-392. [CrossRef]

64. Brun, M.; Di, F.; Bonthoux, S. Residents' perceptions and valuations of urban wastelands are influenced by vegetation structure. Urban For. Urban Green. 2018, 29, 393-403. [CrossRef]

65. Pickett, S.T.A.; Cadenasso, M.L.; Childers, D.L.; McDonnell, M.J.; Zhou, W. Evolution and future of urban ecological science: Ecology in, of, and for the city. Ecosyst. Health Sustain. 2016, 2, e01229. [CrossRef]

66. Williams, N.S.G.; Schwartz, M.W.; Vesk, P.A.; McCarthy, M.A.; Hahs, A.K.; Clemants, S.E.; Corlett, R.T.; Duncan, R.P.; Norton, B.A.; Thompson, K.; et al. A conceptual framework for predicting the effects of urban environments on floras. J. Ecol. 2009, 97, 4-9. [CrossRef]

67. Pickett, S.T.A.; Cadenasso, M.L.; Grove, J.M.; Boone, C.G.; Groffman, P.M.; Irwin, E.; Kaushal, S.S.; Marshall, V.; McGrath, B.P.; Nilon, C.H.; et al. Urban ecological systems: Scientific foundations and a decade of progress. J. Environ. Manag. 2011, 92, 331-362. [CrossRef] [PubMed]

68. George, K.; Ziska, L.H.; Bunce, J.A.; Quebedeaux, B.; Hom, J.L.; Wolf, J.; Teasdale, J.R. Macroclimate associated with urbanization increases the rate of secondary succession from fallow soil. Oecologia 2009, 159, 637-647. [CrossRef] [PubMed]

69. Gregg, J.W.; Jones, C.G.; Dawson, T.E. Urbanization effects on tree growth in the vicinity of New York City. Earth 2003, 424, 183-187. [CrossRef] [PubMed]

70. Ziska, L.H.; Gebhard, D.E.; Frenz, D.A.; Faulkner, S.; Singer, B.D.; Straka, J.G. Cities as harbingers of climate change: Common ragweed, urbanization, and public health. J. Allergy Clin. Immunol. 2003, 111, 290-295. [CrossRef] [PubMed]

71. Williams, N.S.G.; Hahs, A.K.; Vesk, P.A. Urbanisation, plant traits and the composition of urban floras. Perspect. Plant Ecol. Evol. Syst. 2015, 17, 78-86. [CrossRef]

72. Lososová, Z.; Chytrý, M.; Kühn, I.; Hájek, O.; Horáková, V.; Pyšek, P.; Tichý, L. Patterns of plant traits in annual vegetation of man-made habitats in central Europe. Perspect. Plant Ecol. Evol. Syst. 2006, 8, 69-81. [CrossRef]

73. Aronson, M.F.; Nilon, C.H.; Lepczyk, C.A.; Parker, T.S.; Warren, P.S.; Cilliers, S.S.; Goddard, M.A.; Hahs, A.K.; Herzog, C.; Katti, M.; et al. Hieracrhical filters determine community assembly of urban species pools. Ecology 2016, 86, 4-19. [CrossRef]

74. Gilbert, O. The Ecology of Urban Habitats; Springer Science \& Business Media: Berlin, Germany, 2012.

75. Deng, H.; Jim, C.Y. Spontaneous plant colonization and bird visits of tropical extensive green roof. Urban Ecosyst. 2017, 20, 337-352. [CrossRef]

76. Li, X.; Yin, X.; Wang, Y. Diversity and ecology of vascular plants established on the extant world-longest ancient city wall of Nanjing, China. Urban For. Urban Green. 2016, 18, 41-52. [CrossRef]

77. El-Ghani, M.A.; Bornkamm, R.; El-Sawaf, N.; Turky, H. Plant species distribution and spatial habitat heterogeneity in the landscape of urbanizing desert ecosystems in Egypt. Urban Ecosyst. 2011, 14, 585-616. [CrossRef]

78. Schwoertzig, E.; Ertlen, D.; Trémolières, M. Are plant communities mainly determined by anthropogenic land cover along urban riparian corridors? Urban Ecosyst. 2016, 19, 1767-1786. [CrossRef]

79. Cilliers, S.S.; Bredenkamp, G.J. Analysis of the spontaneous vegetation of intensively managed urban open spaces in the Potchefstroom Municipal Area, North West Province, South Africa. S. Afr. J. Bot. 1999, 65, 59-68. [CrossRef] 
80. Müller, A.; Bøcher, P.K.; Fischer, C.; Svenning, J.C. 'Wild' in the city context: Do relative wild areas offer opportunities for urban biodiversity? Landsc. Urban Plan. 2018, 170, 256-265. [CrossRef]

81. Maurer, U.; Peschel, T.; Schmitz, S. The flora of selected urban land-use types in Berlin and Potsdam with regard to nature conservation in cities. Landsc. Urban Plan. 2000, 46, 209-215. [CrossRef]

82. McKinney, M.L. Effects of urbanization on species richness: A review of plants and animals. Urban Ecosyst. 2008, 11, 161-176. [CrossRef]

83. Vitousek, P.M.; Mooney, H.A.; Lubchenco, J.; Melillo, J.M. Human domination of Earth's ecosystems. Science 1997, 277, 494-499. [CrossRef]

84. Pyšek, P. Alien and native species in Central European urban floras: A quantitative comparison. J. Biogeogr. 1998, 25, 155-163. [CrossRef]

85. Aronson, M.F.J.; La Sorte, F.A.; Nilon, C.H.; Katti, M.; Goddard, M.A.; Lepczyk, C.A.; Warren, P.S.; Williams, N.S.G.; Cilliers, S.; Clarkson, B.; et al. A global analysis of the impacts of urbanization on bird and plant diversity reveals key anthropogenic drivers. Proc. R. Soc. B Biol. Sci. 2014, 281, 1-8. [CrossRef] [PubMed]

86. Bornkamm, R. Spontaneous development of urban woody vegetation on differing soils. Flora Morphol. Distrib. Funct. Ecol. Plants 2007, 202, 695-704. [CrossRef]

87. Jim, C.Y. Urban Biogeographical Analysis of Spontaneous Tree Growth on Stone Retaining Walls. Phys. Geogr. 2008, 29, 351-373. [CrossRef]

88. Zipperer, W. Species composition and structure of regenerated and remnant forest patches within an urban landscape. Urban Ecosyst. 2002, 6, 271-290. [CrossRef]

89. Pimentel, D. Biological Invasions: Economic and Environmental Costs of Alien Plant, Animal, and Microbe Species; CRC Press: Boca Raton, FL, USA, 2014.

90. Hejda, M.; Pyšek, P.; Jarošík, V. Impact of invasive plants on the species richness, diversity and composition of invaded communities. J. Ecol. 2009, 97, 393-403. [CrossRef]

91. Vilà, M.; Espinar, J.L.; Hejda, M.; Hulme, P.E.; Jarošík, V.; Maron, J.L.; Pergl, J.; Schaffner, U.; Sun, Y.; Pyšek, P. Ecological impacts of invasive alien plants: A meta-analysis of their effects on species, communities and ecosystems. Ecol. Lett. 2011, 14, 702-708. [CrossRef] [PubMed]

92. Knight, K.S.; Kurylo, J.S.; Endress, A.G.; Stewart, J.R.; Reich, P.B. Ecology and ecosystem impacts of common buckthorn (Rhamnus cathartica): A review. Biol. Invasions 2007, 9, 925-937. [CrossRef]

93. Sharma, G.P.; Raghubanshi, A.S.; Singh, J.S. Lantana invasion: An overview. Weed Biol. Manag. 2005, 5, 157-165. [CrossRef]

94. Kull, C.A.; Rangan, H. The political ecology of weeds: A scalar approach to landscape transformations. In The International Handbook of Political Ecology; Edward Elgar Publishing: Cheltenham, UK, 2015; pp. 487-500. ISBN 9780857936165.

95. Kohli, R.K.; Batish, D.R.; Singh, J.S.; Singh, H.P.; Bhatt, J.R. Plant invasion in India: An overview. In Invasive Alien Plants: An Ecological Appraisal for the Indian Subcontinent; Centre for Agriculture and Bioscience International: Wallingford, UK, 2011; Chapter 1; pp. 1-9.

96. Nowak, D.J.; Hoehn, R.E.; Bodine, A.R.; Greenfield, E.J.; O’Neil-Dunne, J. Urban forest structure, ecosystem services and change in Syracuse, NY. Urban Ecosyst. 2016, 19, 1455-1477. [CrossRef]

97. Sjöman, H.; Morgenroth, J.; Deak, J.; Sæbø, A. Diversification of the urban forest-Can we afford to exclude exotic tree species? Urban For. Urban Green. 2016, 18, 237-241. [CrossRef]

98. Corlett, R.T. Interactions between birds, fruit bats and exotic plants in urban Hong Kong, South China. Urban Ecosyst. 2005, 8, 275-283. [CrossRef]

99. Dearborn, D.C.; Kark, S. Motivations for conserving urban biodiversity. Conserv. Biol. 2010, 24, 432-440. [CrossRef] [PubMed]

100. Beninde, J.; Veith, M.; Hochkirch, A. Biodiversity in cities needs space: A meta-analysis of factors determining intra-urban biodiversity variation. Ecol. Lett. 2015, 18, 581-592. [CrossRef] [PubMed]

101. Friedrich, R.; Philpott, S.M. Nest-site limitation and nesting resources of ants (Hymenoptera: Formicidae) in urban green spaces. Environ. Entomol. 2009, 38, 600-607. [CrossRef] [PubMed]

102. Philpott, S.M.; Cotton, J.; Bichier, P.; Friedrich, R.L.; Moorhead, L.C.; Uno, S.; Valdez, M. Local and landscape drivers of arthropod abundance, richness, and trophic composition in urban habitats. Urban Ecosyst. 2014, 17, 513-532. [CrossRef]

103. Strauss, B.; Biedermann, R. Urban brownfields as temporary habitats: Forces for the driving of phytophagous insects diversity. Ecography 2006, 29, 928-940. [CrossRef] 
104. Angold, P.G.; Sadler, J.P.; Hill, M.O.; Pullin, A.; Rushton, S.; Austin, K.; Small, E.; Wood, B.; Wadsworth, R.; Sanderson, R.; et al. Biodiversity in urban habitat patches. Sci. Total Environ. 2006, 360, 196-204. [CrossRef] [PubMed]

105. Öckinger, E.; Dannestam, Å.; Smith, H.G. The importance of fragmentation and habitat quality of urban grasslands for butterfly diversity. Landsc. Urban Plan. 2009, 93, 31-37. [CrossRef]

106. Yang, L. From Molecules to Ecosystems: How Do Mosquitoes Respond to Changing Environments? Ph.D Thesis, The Ohio State University, Columbus, OH, United States, 2017.

107. Sivakoff, F.S.; Prajzner, S.P.; Gardiner, M.M. Unique bee community assembly within vacant lots and urban farms results from variation in surrounding landscape urbanization intensity. Sustainability 2018, 6, 1926. [CrossRef]

108. Moorhead, L.C.; Philpott, S.M. Richness and composition of spiders in urban green spaces in Toledo Ohio. J. Arachnol. 2013, 41, 356-363. [CrossRef]

109. Burkman, C.E.; Gardiner, M.M. Spider assemblages within greenspaces of a deindustrialized urban landscape. Urban Ecosyst. 2015, 18, 793-818. [CrossRef]

110. Uno, S.; Cotton, J.; Philpott, S.M. Diversity, abundance, and species composition of ants in urban green spaces. Urban Ecosyst. 2010, 13, 425-441. [CrossRef]

111. Gardiner, M.M.; Prajzner, S.P.; Burkman, C.E.; Albro, S.; Grewal, P.S. Vacant land conversion to community gardens: Influences on generalist arthropod predators and biocontrol services in urban greenspaces. Urban Ecosyst. 2014, 17, 101-122. [CrossRef]

112. McIntyre, N.E.; Rango, J.; Fagan, W.F.; Faeth, S.H. Ground arthropod community structure in a heterogeneous urban environment. Landsc. Urban Plan. 2001, 52, 257-274. [CrossRef]

113. Isaacs, R.; Tuell, J.; Fiedler, A.; Gardiner, M.; Landis, D. Maximizing arthropod-mediated ecosystem services in agricultural landscapes: The role of native plants. Front. Ecol. Environ. 2009, 7, 196-203. [CrossRef]

114. McIntyre, N.E. Ecology of Urban Arthropods: A Review and a call to action. Ann. Entomol. Soc. Am. 2000, 93, 825-835. [CrossRef]

115. Šálek, M.; Marhoul, P.; Pintíř, J.; Kopecký, T.; Slabý, L. Importance of unmanaged wasteland patches for the grey partridge Perdix perdix in suburban habitats. Acta Oecol. 2004, 25, 23-33. [CrossRef]

116. Meffert, P.J.; Marzluff, J.M.; Dziock, F. Unintentional habitats: Value of a city for the wheatear (Oenanthe oenanthe). Landsc. Urban Plan. 2012, 108, 49-56. [CrossRef]

117. Hofer, C.; Gallagher, F.J.; Holzapfel, C. Metal accumulation and performance of nestlings of passerine bird species at an urban brownfield site. Environ. Pollut. 2010, 158, 1207-1213. [CrossRef] [PubMed]

118. Chamberlain, D.E.; Toms, M.P.; Cleary-McHarg, R.; Banks, A.N. House sparrow (Passer domesticus) habitat use in urbanized landscapes. J. Ornithol. 2007, 148, 453-462. [CrossRef]

119. Murgui, E. Seasonal patterns of habitat selection of the house sparrow Passer domesticus in the urban landscape of Valencia (Spain). J. Ornithol. 2009, 150, 85-94. [CrossRef]

120. Rega-Brodsky, C.C.; Nilon, C.H. Vacant lots as a habitat resource: Nesting success and body condition of songbirds. Ecosphere 2016, 7, 1-11. [CrossRef]

121. Meffert, P.J.; Dziock, F. The influence of urbanisation on diversity and trait composition of birds. Landsc. Ecol. 2013, 28, 943-957. [CrossRef]

122. Meffert, P.J.; Dziock, F. What determines occurrence of threatened bird species on urban wastelands? Biol. Conserv. 2012, 153, 87-96. [CrossRef]

123. Foster, J. Hiding in plain view: Vacancy and prospect in Paris' Petite Ceinture. Cities 2014, 40, $124-132$. [CrossRef]

124. Grinder, M.I.; Krausman, P.R. Home range, habitat use, and nocturnal activity of coyotes in an urban environment. J. Wildl. Manag. 2001, 65, 887-898. [CrossRef]

125. Parris, K.M. Urban amphibian assemblages as metacommunities. J. Anim. Ecol. 2006, 75, 757-764. [CrossRef] [PubMed]

126. Riley, S.P.D.; Busteed, G.T.; Kats, L.B.; Vandergon, T.L.; Lee, L.F.S.; Dagit, R.G.; Kerby, J.L.; Fisher, R.N.; Sauvajot, R.M. Effects of urbanization on the distribution and abundance of amphibians and invasive species in Southern California streams. Conserv. Biol. 2005, 19, 1894-1907. [CrossRef]

127. Germaine, S.S.; Wakeling, B.F. Lizard species distributions and habitat occupation along an urban gradient in Tucson, Arizona, USA. Biol. Conserv. 2001, 97, 229-237. [CrossRef] 
128. Little, E.; Bajwa, W.; Shaman, J. Local environmental and meteorological conditions influencing the invasive mosquito Ae. albopictus and arbovirus transmission risk in New York City. PLoS Negl. Trop. Dis. 2017, 11, 1-19. [CrossRef] [PubMed]

129. Little, E.; Biehler, D.; Leisnham, P.T.; Jordan, R.; Wilson, S.; LaDeau, S.L. Socio-ecological mechanisms supporting high densities of Aedes albopictus (Diptera: Culicidae) in Baltimore, MD. J. Med. Entomol. 2017, 54, 1183-1192. [CrossRef] [PubMed]

130. LaDeau, S.L.; Leisnham, P.T.; Biehler, D.; Bodner, D. Higher mosquito production in low-income neighborhoods of baltimore and washington, DC: Understanding ecological drivers and mosquito-borne disease risk in temperate cities. Int. J. Environ. Res. Public Health 2013, 10, 1505-1526. [CrossRef] [PubMed]

131. Soulsbury, C.D.; White, P.C.L. Human-wildlife interactions in urban areas: A review of conflicts, benefits and opportunities. Wildl. Res. 2015, 42, 541-553. [CrossRef]

132. Bakken, A.J.; Schoof, S.C.; Bickerton, M.; Kamminga, K.L.; Jenrette, J.C.; Malone, S.; Abney, M.A.; Herbert, D.A.; Reisig, D.; Kuhar, T.P.; et al. Occurrence of brown marmorated stink bug (Hemiptera: Pentatomidae) on wild hosts in Nonmanaged Woodlands and soybean fields in North Carolina and Virginia. Environ. Entomol. 2015, 44, 1011-1021. [CrossRef] [PubMed]

133. Barringer, L.E.; Donovall, L.R.; Spichiger, S.-E.; Lynch, D.; Henry, D. The First New World Record of Lycorma delicatula (Insecta: Hemiptera: Fulgoridae). Entomol. News 2015, 125, 20-23. [CrossRef]

134. Bolund, P.; Hunhammar, S. Ecosystem services in urban areas. Ecol. Econ. 1999, 29, 293-301. [CrossRef]

135. De Groot, R.S.; Wilson, M.A.; Boumans, R.M.J. A typology for the classification, description and valuation of ecosystem functions, goods and services. Ecol. Econ. 2002, 41, 393-408. [CrossRef]

136. Elmqvist, T.; Fragkias, M.; Goodness, J.; Güneralp, B.; Marcotullio, P.J.; McDonald, R.I.; Parnell, S.; Schewenius, M.; Sendstad, M.; Seto, K.C.; et al. Urbanization, Biodiversity and Ecosystem Services: Challenges and Opportunities; Springer: Berlin/Heidelberg, Germany, 2013; ISBN 9789400770881.

137. Reid, W.V. Millennium Ecosystem Assessment. In Ecosystems and Human Well-Being: Synthesis; Island Press: Washington, DC, USA, 2005.

138. Gomez-Baggethunm, E.; Gren, Å.; Barton, D.N.; Langemeyer, J.; McPhearson, T.; O'Farrell, P.; Andersson, E.; Hamstead, Z.A.; Kremer, P. Urban ecosystem services. In Urbanization, Biodiversity and Ecosystem Services: Challenges and Opportunities; Springer: Berlin, Germany, 2013; Chapter 11; pp. 175-252.

139. Kim, G.; Miller, P.A.; Nowak, D.J. Assessing urban vacant land ecosystem services: Urban vacant land as green infrastructure in the City of Roanoke, Virginia. Urban For. Urban Green. 2015, 14, 519-526. [CrossRef]

140. Miller, J.R. Biodiversity conservation and the extinction of experience. Trends Ecol. Evol. 2005, 20, 430-434. [CrossRef] [PubMed]

141. Soga, M.; Gaston, K.J. Extinction of experience: The loss of human-nature interactions. Front. Ecol. Environ. 2016, 14, 94-101. [CrossRef]

142. Lee, A.C.K.; Maheswaran, R. The health benefits of urban green spaces: A review of the evidence. J. Public Health 2011, 33, 212-222. [CrossRef] [PubMed]

143. Jim, C.Y.; Chen, W.Y. Bioreceptivity of buildings for spontaneous arboreal flora in compact city environment. Urban For. Urban Green. 2011, 10, 19-28. [CrossRef]

144. Millard, A. Indigenous and spontaneous vegetation: Their relationship to urban development in the city of Leeds, UK. Urban For. Urban Green. 2004, 3, 39-47. [CrossRef]

145. Rupprecht, C.D.D.; Byrne, J.A.; Ueda, H.; Lo, A.Y. “It's real, not fake like a park”: Residents' perception and use of informal urban green-space in Brisbane, Australia and Sapporo, Japan. Landsc. Urban Plan. 2015, 143, 205-218. [CrossRef]

146. Heynen, N.; Perkins, H.A.; Parama, R. The political ecology of uneven urban green space. Urban Aff. Rev. 2006, 42, 3-25. [CrossRef]

147. Schwarz, K.; Fragkias, M.; Boone, C.G.; Zhou, W.; McHale, M.; Grove, J.M.; O’Neil-Dunne, J.; McFadden, J.P.; Buckley, G.L.; Childers, D.; et al. Trees grow on money: Urban tree canopy cover and environmental justice. PLoS ONE 2015, 10, e0122051. [CrossRef] [PubMed]

148. Greene, C.S.; Robinson, P.J.; Millward, A.A. Canopy of advantage: Who benefits most from city trees? J. Environ. Manag. 2018, 208, 24-35. [CrossRef] [PubMed]

149. Astell-Burt, T.; Feng, X.; Mavoa, S.; Badland, H.M.; Giles-Corti, B. Do low-income neighbourhoods have the least green space? A cross-sectional study of Australia's most populous cities. BMC Public Health 2014, 14, 1-11. [CrossRef] [PubMed] 
150. De Vries, S.; van Dillen, S.M.E.; Groenewegen, P.P.; Spreeuwenberg, P. Streetscape greenery and health: Stress, social cohesion and physical activity as mediators. Soc. Sci. Med. 2013, 94, 26-33. [CrossRef] [PubMed]

151. Kuo, F.E.; Bacaicoa, M.; Sullivan, W.C. Transforming inner city landscapes: Trees, sence of safety, and preference. Environ. Behav. 1998, 30, 28-59. [CrossRef]

152. Ard, K.; Colen, C.; Becerra, M.; Velez, T. Two mechanisms: The role of social capital and industrial pollution exposure in explaining racial disparities in self-rated health. Int. J. Environ. Res. Public Health 2016, 13, 1025. [CrossRef] [PubMed]

153. Nassauer, J.I.; Raskin, J. Urban vacancy and land use legacies: A frontier for urban ecological research, design, and planning. Landsc. Urban Plan. 2014, 125, 245-253. [CrossRef]

154. Rupprecht, C.D.D.; Byrne, J.A.; Lo, A.Y. Memories of vacant lots: How and why residents used informal urban green space as children and teenagers in Brisbane, Australia, and Sapporo, Japan. Child. Geogr. 2016, 14, 340-355. [CrossRef]

155. Kahn, P.H. Children's affiliations with nature: Structure, development, and the problem of environmental generational amnesia. In Children and Nature: Psychological, Sociocultural, and Evolutionary Investigations; MIT Press: Cambridge, MA, USA, 2002; pp. 92-115. ISBN 0-262-11267-1.

156. The Cuyahoga County Planning Commission; Cleveland Metroparks. Cuyahoga County Urban Tree Canopy Assessment, 2013; The Cuyahoga County Planning Commission: Cleveland, OH, USA, 2013.

157. Homer, C.G.; Dewitz, J.A.; Yang, L.; Jin, S.; Danielson, P.; Xian, G.; Coulston, J.; Herold, N.D.; Wickham, J.D.; Megown, K. Completion of the 2011 National Land Cover Database for the conterminous United States-Representing a decade of land cover change information. Photogramm. Eng. Remote Sens. 2015, 81, 345-354.

158. Green, O.O.; Garmestani, A.S.; Albro, S.; Ban, N.C.; Berland, A.; Burkman, C.E.; Gardiner, M.M.; Gunderson, L.; Hopton, M.E.; Schoon, M.L.; et al. Adaptive governance to promote ecosystem services in urban green spaces. Urban Ecosyst. 2015, 19, 77-93. [CrossRef]

159. Hofmann, M.; Westermann, J.R.; Kowarik, I.; Van der Meer, E. Perceptions of parks and urban derelict land by landscape planners and residents. Urban For. Urban Green. 2012, 11, 303-312. [CrossRef]

160. Németh, J.; Langhorst, J. Rethinking urban transformation: Temporary uses for vacant land. Cities 2014, 40, 143-150. [CrossRef]

161. Kremer, P.; Hamstead, Z.A.; McPhearson, T. A social-ecological assessment of vacant lots in New York City. Landsc. Urban Plan. 2013, 120, 218-233. [CrossRef]

162. Nassauer, J.I. Care and stewardship: From home to planet. Landsc. Urban Plan. 2011, 100, 321-323. [CrossRef]

163. Nassauer, J.I. Messy Ecosystems, Orderly frames. Landsc. J. 1995, 14, 161-170. [CrossRef]

164. Mair, C.; Kaplan, G.A.; Everson-Rose, S.A. Are there hopeless neighborhoods? An exploration of environmental associations between individual-level feelings of hopelessness and neighborhood characteristics. Health Place 2012, 18, 434-439. [CrossRef] [PubMed]

165. Curley, A.M. Neighborhood institution, facilities, and public space: A missing link for HOPE VI residents' development of social capital? Cityscape J. Policy Dev. Res. 2010, 12, 33-64. [CrossRef]

166. Wen, M.; Zhang, X.; Harris, C.D.; Holt, J.B.; Croft, J.B. Spatial disparities in the distribution of parks and green spaces in the USA. Ann. Behav. Med. 2013, 45, 18-27. [CrossRef] [PubMed]

167. Durant, N.; Kerr, J.; Harris, S.K.; Saelens, B.E.; Norman, G.J.; Sallis, J.F. Environmental and safety barriers to youth physical activity in neighborhood parks and streets: Reliability and validity. Pediatr. Exerc. Sci. 2009, 21, 86-99. [CrossRef] [PubMed]

168. Kuo, F.E.; Sullivan, W.C. Environment and crime in the inner city: Does vegetation reduce crime? Environ. Behav. 2001, 33, 343-367. [CrossRef]

169. Wolfe, M.K.; Mennis, J. Does vegetation encourage or suppress urban crime? Evidence from Philadelphia, PA. Landsc. Urban Plan. 2012, 108, 112-122. [CrossRef]

170. Branas, C.C.; Cheney, R.A.; MacDonald, J.M.; Tam, V.W.; Jackson, T.D.; Ten Havey, T.R. A difference-indifferences analysis of health, safety, and greening vacant urban space. Am. J. Epidemiol. 2011, 174, 1296-1306. [CrossRef] [PubMed]

171. Garvin, E.C.; Cannuscio, C.C.; Branas, C.C. Greening vacant lots to reduce violent crime: A randomised controlled trial. Inj. Prev. 2013, 19, 198-203. [CrossRef] [PubMed]

172. Troy, A.; Morgan Grove, J.; O'Neil-Dunne, J. The relationship between tree canopy and crime rates across an urban-rural gradient in the greater Baltimore region. Landsc. Urban Plan. 2012, 106, 262-270. [CrossRef] 
173. Locke, D.H.; Han, S.H.; Kondo, M.C.; Murphy-Dunning, C.; Cox, M. Did community greening reduce crime? Evidence from New Haven, CT, 1996-2007. Landsc. Urban Plan. 2017, 161, 72-79. [CrossRef]

174. Palmer, M.A. Socioenvironmental sustainability and actionable ccience. Bioscience 2012, 62, 5-6. [CrossRef]

175. Shwartz, A.; Turbé, A.; Julliard, R.; Simon, L.; Prévot, A.C. Outstanding challenges for urban conservation research and action. Glob. Environ. Chang. 2014, 28, 39-49. [CrossRef] 